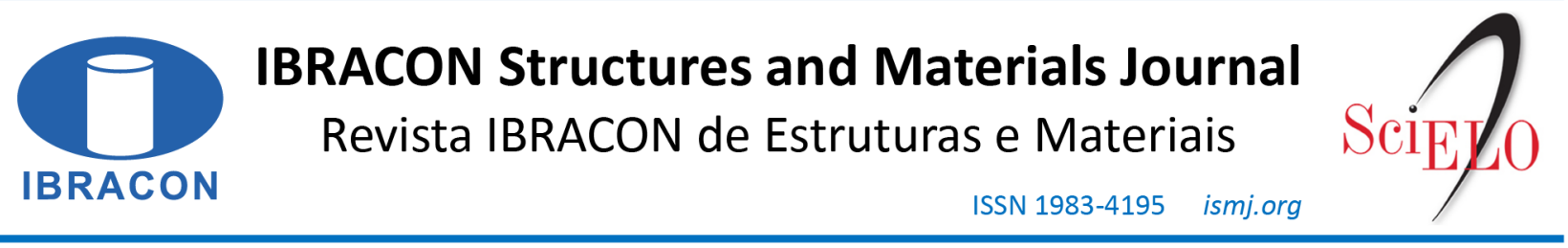

ORIGINAL ARTICLE

\title{
Optimization of the structural system with composite beam and composite slab using Genetic Algorithm
}

\section{Otimização do sistema estrutural viga mista e laje mista com utilização de Algoritmo Genético}

\author{
Breno Dias Breda ${ }^{\mathrm{a}}$ \\ Tiago Cetto Pietralonga ${ }^{a}$ (ic) \\ Élcio Cassimiro Alves ${ }^{\mathrm{a}}$ (D)
}

${ }^{a}$ Universidade Federal do Espírito Santo - UFES, Departamento de Engenharia Civil, Vitória, ES, Brasil

Received 05/Sep/2019

Accepted 25/Mar/2020

\begin{abstract}
The objective of this research is to create a software to optimize choice variables adopted by an engineer in a structural system with steel-concrete composite beams and steel decks, such as: beam shape, composite slab sheeting, number and spacing of beams, slab thickness and interaction ratio between beam and slab. To accomplish this, a program that uses the Genetic Algorithm optimization tool provided by Matlab R2015a was developed. To meet safety requirements, restrictions on the Ultimate Limit State were implemented in the code, following the normative requirements of ABNT NBR 8800: 2008. Case studies of a problem found in the literature and another of a real structure, are presented to serve as references for software evaluation. Results indicate that the use of optimization processes is fundamental to design increasingly cost-effective structures.
\end{abstract}

Keywords: optimization, genetic algorithm, composite beam, composite slab.

Resumo: O objetivo deste trabalho é apresentar uma formulação computacional que otimize as variáveis de escolha a serem adotadas pelo engenheiro em um projeto de viga mista metálica com steel deck. Para esse fim foi utilizado o programa Matlab R2015a que possui uma ferramenta de otimização que utiliza o AG. Para atender os requisitos de segurança, restrições considerando o ELU são consideradas no código do programa elaborado, seguindo as prescrições normativas da ABNT NBR 8800:2008. Estudos de casos de um problema encontrado na literatura e de uma estrutura real, uma laje de sala de aula em um edifício de dois pavimentos, são apresentados a fim de servirem de referência para aferição e avaliação do programa. Os resultados permitem concluir que a utilização de processos de otimização é fundamental para obtenção de projetos cada vez mais economicamente vantajosos.

Palavras-chave: otimização, algoritmo genético, viga mista, laje mista.

How to cite: B. D. Breda, T. C. Pietralonga, and E. C. Alves, "Optimization of the structural system with composite beam and composite slab using genetic algorithm,” Rev. IBRACON Estrut. Mater., vol. 13, no. 6, e13602, 2020, https://doi.org/10.1590/S1983-41952020000600002

\section{INTRODUCTION}

Structural optimization is a method aimed at reducing the construction cost of a given structural design as much as possible, without detriments to structural safety. A good optimization process is one in which the modelled structure and considerations regarding chosen design variables closely resemble actual service conditions. Examples of appropriate structural optimizations include the works conducted by Lazzari, Alves and Calenzani [1]; Lubke, Alves and Azevedo [2] and Breda et al. [3].

Among the optimization methods currently available, Genetic Algorithms (GA) stand out due to the possibility of working with discrete variables, making GA the recommended approach for optimizing structural systems featuring 
steel-concrete composite beams and slabs, since these systems can be designed with the aid of tables provided by manufacturers.

In the 1960s, John Holland, regarded as the creator of the GA, relied on the principle of Mendelian inheritance and Darwin's natural selection to create the basis of the algorithm within the principles of meta-heuristics. In other words, Holland created an iterative process that uses random choices combined with knowledge of previous answers to achieve an overall optimal value, avoiding local instances of said value.

The system of composite beams combined with composite slabs with built-in steel sheeting, also known as steel deck (Figure 1), is a structural solution that stands out for reductions in construction time and usages of wooden formwork and shoring. The design of the composite slab is relatively complex; however, manufacturers of the steel formwork usually provide simplified design tables, making the design process easier and ideal for the implementation of GA.

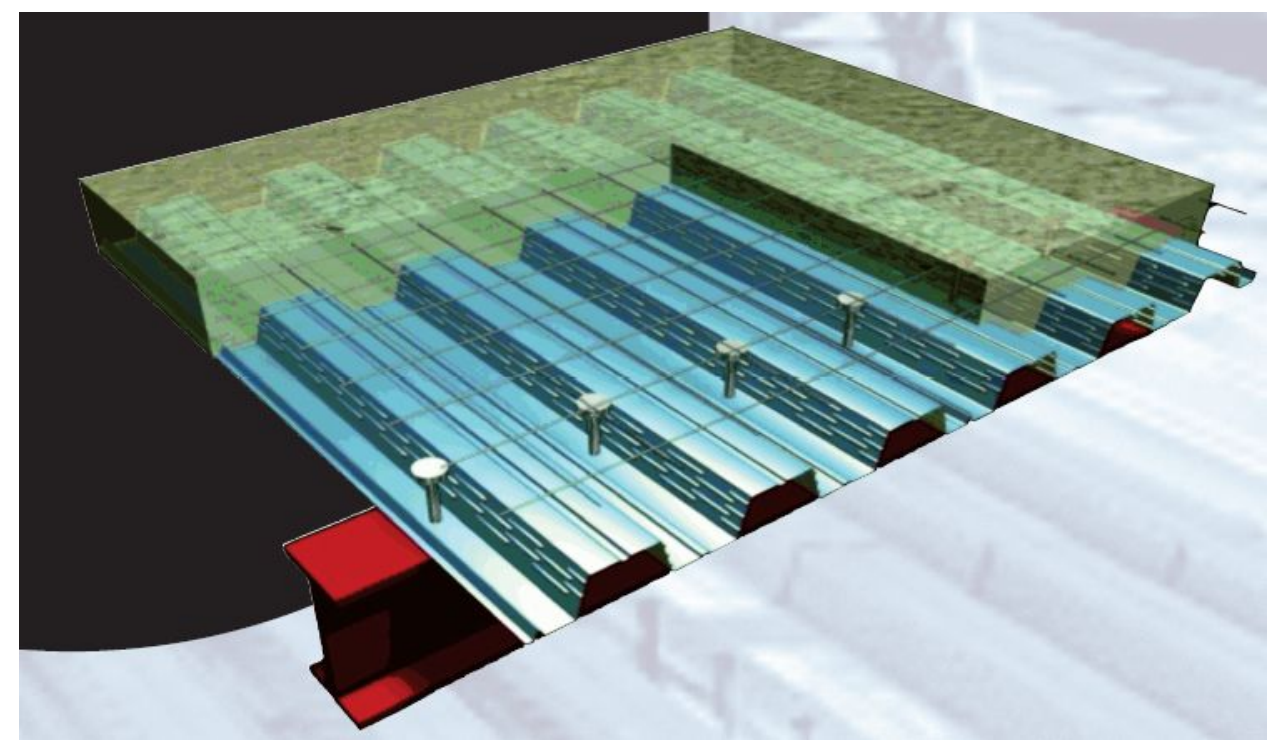

Figure 1 - Composite beam system with composite slab (Metform [4]).

Some of the different applications of GA in engineering are presented by Liu and Hammad [5]. In 1997, the authors performed an optimization study for bridge recovery using genetic algorithms, forming a model with multiple objective functions, and combining the different results with an approach based on the Pareto principle. The optimization study aimed to reduce the cost of bridge recovery and the degree of deterioration, concluding that GA presents excellent results even in a model with multiple objectives, and without requiring much time to perform calculations.

Cho, Min and Lee [6] carried out an optimization study in 2001 using GA to evaluate the life cycle cost of bridges with orthotropic steel deck systems, which consists of steel slabs with ribbed formwork reinforced longitudinally, transversely, or in both directions. In this life cycle analysis, building and maintenance costs were considered, with adjustments in structural resistance, deflection, and fatigue. The study concludes that optimization analyses lead to a more rational, economical, and safer design when compared to conventional design methods.

Kuan-Chen Fu, Zhai and Zhou [7] used GA in 2005 to find optimized solutions for bridges with steel beams. The main objective was to minimize the weight, and consequently the cost of the structure. Bridges with single span and continuous beams of various lengths were analyzed. The GA presented satisfactory results, emphasizing its proximity to actual service conditions when discrete variables are used.

Also, in 2005, Souza Junior [8] carried out a study that implemented GA on the global mechanical behavior of spatial steel tubular structures. This research assessed total steel consumption for several geometric configurations, focusing on solutions to minimize it.

In 2008, Câmara Neto, Landesmann and Batista [9] presented an application of GA on the design of steel-concrete composite beams in multi-story buildings. The study sought alternatives to lower costs while still abiding by safety criteria for room and fire temperatures, the latter prescribed in design standards EuroCode 4 and ABNT NBR 14323: 1999. Different laminated steel profiles were considered, combining different steel reinforcement rates and thicknesses of fire protection materials. 
Still in 2008, Forti and Requena [10] developed a software to optimize the structural design of large steel roofs using GA, seeking to improve the structural design of single and multiplane trusses by varying specific parameters. Software tests concluded that GA optimization presents good results for this type of structure.

Lima [11] developed an optimization software in 2011 using GA applied to reinforced concrete beams, using discrete variables to better represent the variables of choice in each structural design. The use of GA provided significant improvements, especially in complex scenarios and with constant restrictions. Furthermore, in $85 \%$ of the cases, optimization procedures led to overall optimal solutions.

Kripakaran and Gupta [12] developed, also in 2011, a decision support system based on GA applied to steel frames, with various connection types. The study highlights the advantages of using discrete variables with GA. This feature is explored in the software later presented herein.

Kociecki and Adeli [13] and Prendes-Gero et al. [14] implemented GA for optimization of different steel structural systems in 2015 and 2018, respectively, and observed gains of around 10\% when compared to non-optimized designs. Both studies also highlighted the ability to work with discrete variables when using GA as an important characteristic for obtaining good results.

Bilbao [15] presented in 2016 a study of optimal design of a tuned mass damper with GA in prefabricated slabs. Results proved to be valid when compared to existing design abacuses in the literature.

Bezerra [16] implemented, in 2017, a MATLAB code to optimize the cost of reinforced concrete beams using GA. Optimized variables included effective depth, beam width and the areas of longitudinal and transverse reinforcement steel. The author observed gains of around $2 \%$ when compared to other optimization methods.

Malveiro et al. [17] implemented GA in a 2018 study of bridges and viaducts using finite element models validated with experimental tests. The GA was used to perform a calibration of parameters, calculating the optimal values of the most significant physical properties to increase the correlation of numerical results with those obtained experimentally.

Studies addressing the optimization of composite structures are observed in Lima et al. [18]. As an example, in 2008 the authors used GA to assess design problems related to vibration in steel-concrete composite walkways, considering international criteria for assessing human comfort in structures of this type aimed at pedestrian use. The study sought to maximize allowable spans using said criteria along with standardized design recommendations concerning serviceability and ultimate limit states.

Pereira [19] conducted a 2016 study of optimization on composite beams used in bridges to reduce the dimensions of bridge decks. The optimization was implemented with Microsoft Excel and focused on resizing the support beams. Analyses yielded satisfactory results, indicating a reduction of $7.8 \%$ in the final cost of construction.

Papavasileiou and Charmpis [20] carried out, also in 2016, a study to optimize the costs of composite steel and concrete beams and columns in multi-story buildings, considering static and seismic loading. The authors implemented optimization via Evolution Strategies, a probabilistic method like the GA. The method proved to be efficient when applied to practical scenarios.

In 2018, Silva and Rodrigues [21] presented an optimization study of composite beams in which the structural design was performed using an iterative method of sequential linear programming as an optimization process. This approach sought to reduce consumption of materials via variation of parameters such as: cross-section geometry of the concrete slab and the beam, as well as the area of steel reinforcement.

Tormem et al. [22] published, in 2019, a research on the optimization of steel-concrete composite beams with welded steel profiles using the harmonic search optimization method. Profile geometries were selected as discrete variables and the design procedures followed standards such as ABNT 8800: 2008 and ABNT 5884: 2013. Overall, results proved to be quite efficient, minimizing costs.

The present research seeks to develop a computational tool that optimizes the choice variables adopted by engineers when designing structural systems featuring steel-concrete composite beams and slabs, such as: beam profile, slab profile sheeting, quantity and spacing of secondary beams, slab thickness and the degree of interaction between beam and slab.

The optimization is carried out in compliance with safety requirements, added to the software as restrictions considering Ultimate Limit State (ULS) design, according to design prescriptions from ABNT NBR 8800: 2008 [23].

Two problems are presented for validation and evaluation of the developed software. The first is an example of simplified optimization presented by Fakury, Silva and Caldas [24]. The second is a comparison with an existing structure that uses the steel deck as a floor system.

Furthermore, it is essential to emphasize the relevance of this work, considering the lack of optimization studies using the GA method applied to systems featuring composite slabs with profile sheeting in combination with steelconcrete composite beams. 


\section{METHODOLOGY}

\subsection{Genetic Algorithm}

According to the Matlab R2015a documentation [25], the steps for solving an optimization problem via GA are as follows:

i. The algorithm creates an initial random population;

ii. A sequence of new populations is created. At each step, individuals of the current generation are used to create the next population. New populations, in turn, are obtained from the following steps:

a. Evaluation of each individual within the population according to the value returned by the algorithm when calculating the objective function (fitness value);

b. Application of a scale factor to the gross values from the previous step to convert them into a range that is easier to use;

c. Selection of individuals, called parents, based on their fitness value;

d. Some individuals in the current population who have better fitness values are chosen as the elite. These individuals are kept in the next population;

e. Production of offspring from parents by making random changes to a single parent (mutation) or by combining vector input information from a pair of parents (crossing);

f. Replacement of individuals in the current population with offspring, forming the next population.

iii. The algorithm stops when one of the stop criteria is met.

Thus, it can be understood that an individual is a possible answer to the problem studied and the population is a set of individuals.

The stopping criteria used by the GA are:

i. Number of generations (MaxGenerations), with a default value of 100 times the number of variables;

ii. Time limit (MaxTime), for which the default value is infinite;

iii. Optimal predetermined value reached (FitnessLimit), with a default value of negative infinity, that is, the lowest possible;

iv. Small or no variation in the best response between a given number of generations (MaxStallGenerations), with a default value of 50 generations;

v. Small or no variation in the best response over a period of time (MaxStallTime), with a default value of infinity;

The tolerance, or precision of the values, returned by the objective function is $10^{-6}$ and for the calculation of the restrictions, $10^{-3}$.

\subsection{Scope of the software}

The software detailed in this paper was implemented in Matlab R2015a [25], the GA is native to the program, and is used here with its default parameters. The software uses the following underlying principles:

- Considers the slab as composite, supported by composite secondary beams, connected by stud-bolts;

- Optimizes the profile of the secondary beam using the table of laminated profiles from Gerdau [26];

- Optimizes the composite slab (steel deck thickness, maximum span, height of the concrete layer). The steel deck is selected from the Metform load-span table [4], which can be MF-50 or MF-75;

- Considers that the load is uniformly distributed over the slab.

Optimization of secondary composite beams is performed with the software developed by Breda et al. [3], changing only the way the variables to be optimized are treated, taken as discrete in this case. The restrictions regarding the beams are discussed in more detail in Breda et al. [3].

The initial population contains 120 individuals and the following, 60 . The rate of elite individuals and crossing of the intermediate type are 0.05 and 0.8 , respectively, whereas the mutation rate is random. The GA is performed primarily with an entirely random initial population, thereby obtaining an optimal local response. Then the algorithm is executed again with the previously obtained answer added to the initial population. More details can be found on the Matlab documentation.

\subsection{Choice variables}

The choice variables, or individuals, are represented by a $1 \mathrm{x} 6$ vector, where each element represents, respectively: 
- The line number of Gerdau [26] profile table that represents the profile analyzed. The values are taken from the table for: profile height $(\mathrm{d})$, flange width $\left(\mathrm{b}_{\mathrm{f}}\right)$, web thickness $\left(\mathrm{t}_{\mathrm{w}}\right)$ and flange thickness $\left(\mathrm{t}_{\mathrm{f}}\right)$. This value ranges from 1 to 88 for the laminated profiles table;

- The line number of the table of values for the interaction ratio of the slab-beam analyzed. This value ranges from 1 to 100 , the values in the table range from 0 to 1 , with an accuracy of two decimal places;

- The line number of the Metform [4] table that represents the incorporated formwork for the composite slab analyzed. This value ranges from 1 to 24 ;

- The column number of the Metform [4] table, which represents the maximum span of the composite slab analyzed. This value ranges from 1 to 16 ;

- Value used to alternate the orientation of the secondary beams, between transversal and longitudinal. This value alternates between 1 and 2;

- Value used to switch between Metform sheeting types [4]. This element takes the value of 1 for MF-50 and 2 for MF-75.

By simple combinatorial analysis, the universe of possible responses, including viable and non-viable responses, has $13,516,800$ possibilities.

\subsection{Fitness function}

The fitness function $(f)$ determines the value to be optimized, which for the present case is the cost of the composite beam/slab structural system. The function $\mathrm{f}$ is given by Equation 1 .

$f=C_{\text {beam }}+C_{\text {connector }}+C_{\text {formwork }}+C_{\text {concrete }}+C_{\text {mesh }}$

where: $C_{\text {beam }}=$ total cost of the beams $(\mathrm{R} \$)$, given by Equation $2 ; C_{\text {connector }}=$ cost of the connectors $(\mathrm{R} \$)$, given by Equation 3; $C_{\text {formwork }}=$ total cost of the steel profile sheeting (R\$), given by Equation 4; $C_{\text {concrete }}=$ total cost of concrete used in the composite slab (R\$), given by Equation 5; and $C_{m e s h}=$ total cost of the welded wire reinforcing mesh of the composite slab (R\$), given by Equation 6.

$C_{\text {beam }}=n_{\text {beam }} \cdot \rho_{\text {steel }} \cdot\left(A_{\text {beam }} \cdot L_{\text {beam }}\right) \cdot c_{\text {beam }}$

where: $n_{\text {beam }}=$ number of beams adopted in the solution (un.); $\rho_{\text {steel }}=$ specific mass of profile steel, adopted as 0.00785 $\mathrm{kg} / \mathrm{cm}^{3} ; A_{\text {beam }}=$ cross section area of beam profile $\left(\mathrm{cm}^{2}\right)$; and $L_{\text {beam }}=$ beam length $(\mathrm{cm}) ;$ and $c_{\text {beam }}=$ unit cost of steel profile of the beam $(\mathrm{R} \$ / \mathrm{kg})$.

$C_{\text {connector }}=n_{\text {connector }} \cdot c_{\text {connector }}$

where: $n_{\text {connector }}=$ number of shear connectors adopted in the solution (un.); and $c_{\text {connector }}=$ unit cost of the shear connector (R\$/un).

$C_{\text {formwork }}=A_{\text {slab }} \cdot c_{\text {formwork }}$

where: $A_{\text {slab }}=$ rectangular slab area covered by profiled sheeting $\left(\mathrm{cm}^{2}\right)$; and $c_{\text {formwork }}=$ unit cost of the profile sheeting $\left(\mathrm{R} \$ / \mathrm{cm}^{2}\right)$.

$C_{\text {concrete }}=v_{\text {concrete }} \cdot A_{\text {slab }} \cdot c_{\text {concrete }}$ 
where: $v_{\text {concrete }}=$ unitary concrete consumption, obtained from Metform's [4] load-span table $\left(\mathrm{cm}^{3} / \mathrm{cm}^{2}\right)$; and $c_{\text {concrete }}=$ unit cost of concrete used in the slab $\left(\mathrm{R} \$ / \mathrm{cm}^{3}\right)$.

$C_{\text {mesh }}=p_{\text {mesh }} \cdot A_{\text {slab }} \cdot c_{\text {mesh }}$

where: $p_{\text {mesh }}$ unit consumption of slab welded wire reinforcement, obtained from Metform's [4] load-span table $\left(\mathrm{kg} / \mathrm{cm}^{2}\right)$; and $c_{\text {mesh }}=$ unit cost of welded wire reinforcement $(\mathrm{R} \$ / \mathrm{kg})$.

\subsection{Restrictions}

The constraint function (C), given by a system of equations, gathers the conditions that must be met for a given answer to be accepted as a solution to the problem. As such, restrictions are generally based on standardized requirements such as those prescribed in ABNT NBR 8800: 2008 [23]. For this case, function C is given by Equation 7.

$$
C=\left\{\begin{array}{c}
C_{1}: \frac{h_{w} / t_{w}}{5.7 \sqrt{E / f_{y k}}}-1 \leq 0 \\
C_{2}: \frac{\alpha_{\min }}{\alpha}-1 \leq 0 \\
C_{3}: \frac{M_{s d}}{M_{r d}}-1 \leq 0 \\
C_{4}: \frac{V_{s d}}{V_{r d}}-1 \leq 0 \\
C_{5}: \frac{q_{s d}}{q_{r d}}-1 \leq 0
\end{array}\right.
$$

where:

$C_{1}$ prevents the use of profiles with slender webs in composite structures;

where: $h_{w}=$ profile web height $(\mathrm{cm}) ; t_{w}=$ profile web thickness $(\mathrm{cm}) ; E=$ elasticity modulus of steel $\left(\mathrm{kN} / \mathrm{cm}^{2}\right)$; and $f_{y k}=$ characteristic value of yield strength of profile steel $\left(\mathrm{kN} / \mathrm{cm}^{2}\right)$.

$C_{2}$ does not allow interaction ratios between beam and slab below the minimum value;

where: $\alpha_{\min }=$ minimum interaction ratio between beam and slab given by ABNT NBR 8800: 2008 as a function of material, shape and length of the beam; and $\alpha=$ interaction ratio between beam and slab of the structure.

$C_{3}$ checks if the design bending moment is less than the resistant bending moment;

where: $M_{s d}=$ design bending moment on the structure $(\mathrm{kN} . \mathrm{cm})$; and $M_{r d}=$ resistant design bending moment $(\mathrm{kN} . \mathrm{cm})$. $C_{4}$ checks if the design shear force is less than the resistant shear force;

where: $V_{s d}=$ design shear force on the structure $(\mathrm{kN})$; and $V_{r d}=$ resistant design shear force $(\mathrm{kN})$.

$C_{5}$ checks if the live load acting on the slab is less than the value allowed by the manufacturer;

where: $q_{s d}=$ live load uniformly distributed on the slab $\left(\mathrm{kN} / \mathrm{cm}^{2}\right)$; and $q_{r d}=$ maximum live load (superimposed load) resisted by the composite slab depending on the span, type of formwork and height of the concrete layer, obtained from Metform's [4] load-span table $\left(\mathrm{kN} / \mathrm{cm}^{2}\right)$.

\subsection{Loading and resistance}

The calculation of the design load adopted for the slab using the Metform [4] tables, does not consider resistance factors, that is, the characteristic values of the loads are adopted, disregarding dead load, in accordance to recommendations from the manufacturer.

Stresses on the beams are obtained considering resistance factors prescribed in ABNT NBR 8800: 2008 [23], with a value of 1.4 for gravitational loads (mainly due to concrete) and 1.5 for live loads. The design loads for slab and beam are given by equations 8 and 9 below: 
$q_{d, \text { slab }}=P_{p, \text { surfacing }} \cdot Q_{\text {overload }}$

$q_{d, \text { beam }}=1.4\left(P_{p, \text { structure }}+P_{p, \text { surfacing }}\right)+1.5\left(Q_{\text {liveload }} \cdot A_{\text {influence }}\right)$

The loading on the slab is not calculated, since design is performed by comparing the load acting on the slab and the load resisted by the slab, according to the manufacturer. Alternatively, loads acting on the secondary beams are calculated considering these elements as simply supported, subjected to a uniformly distributed linear load. The calculation of the internal and resistant stresses of the beams is assessed in more detail by Breda et al. [3].

\subsection{Input data}

To begin the solution, specific parameters must be inserted into the software. These parameters are shown in Table 1, which also details the values adopted for the problems analyzed herein. The unit costs of the materials were taken from the sources mentioned in Table 1 . The costs chosen are compatible with those usually practiced in the Brazilian market.

Table 1 - Input data.

\begin{tabular}{|c|c|c|}
\hline Parameter & Unit & Value adopted \\
\hline \multicolumn{3}{|l|}{ Slab - rectangular (axb) } \\
\hline Slab Type & & Floor \\
\hline $\mathrm{a}$ & $\mathrm{cm}$ & See problem \\
\hline $\mathrm{b}$ & $\mathrm{cm}$ & See problem \\
\hline Uniformly distributed design load - $\mathrm{q}_{\mathrm{d}}$ & $\mathrm{kN} / \mathrm{cm}^{2}$ & See problem \\
\hline \multicolumn{3}{|l|}{ Steel beam properties } \\
\hline Characteristic yield strength of steel - $f_{y k}$ & $\mathrm{kN} / \mathrm{cm}^{2}$ & 34.5 \\
\hline Resistance factor of steel $-\gamma_{\mathrm{a}}$ & & 1.1 \\
\hline Unit cost of steel - cbeam (SINAPI [27]) & $\mathrm{R} \$ / \mathrm{kg}$ & 7.96 \\
\hline \multicolumn{3}{|l|}{ Concrete properties } \\
\hline Type of agregate & & Granite \\
\hline Characteristic compressive strength of concrete $-f_{c k}$ & $\mathrm{kN} / \mathrm{cm}^{2}$ & 3 \\
\hline Resistance factor of concrete strength $-\gamma_{c}$ & & 1.4 \\
\hline Unit cost of concrete $-\mathrm{c}_{\text {concrete }}$ (SINAPI [27]) & $\mathrm{R} \$ / \mathrm{cm}^{3}$ & 0.000346 \\
\hline \multicolumn{3}{|l|}{ Shear connector properties } \\
\hline Diameter $-\mathrm{d}_{\mathrm{cs}}$ & $\mathrm{cm}$ & 1.9 \\
\hline Ultimate tensile strength of the connector - fucs & $\mathrm{kN} / \mathrm{cm}^{2}$ & 41.5 \\
\hline Resistance factor of connector $-\gamma_{\mathrm{cs}}$ & & 1.25 \\
\hline Coefficient for considering the effect of connector grouping $-\mathrm{R}_{\mathrm{g}}$ & & 1.0 \\
\hline Coefficient for considering the position of the connector $-R_{p}$ & & 1.0 \\
\hline Connector unit cost $-\mathrm{c}_{\text {connector }}($ Cordeiro $[28])$ & $\mathrm{R} \$ / \mathrm{un}$ & 11.40 \\
\hline \multicolumn{3}{|l|}{ Welded wire reinforcement } \\
\hline Unit cost of welded mesh $-\mathrm{c}_{\text {mesh }}$ (SINAPI [27]) & $\mathrm{R} \$ / \mathrm{kg}$ & 7.01 \\
\hline \multicolumn{3}{|l|}{ Built-in steel sheeting } \\
\hline \multicolumn{3}{|l|}{ 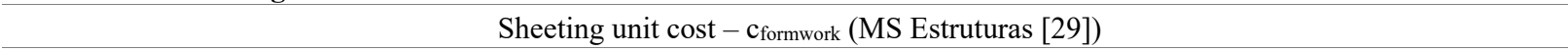 } \\
\hline MF-50, thickness $0.80 \mathrm{~mm}$ & $\mathrm{R} \$ / \mathrm{cm}^{2}$ & 0.007236 \\
\hline MF-50, thickness $0.95 \mathrm{~mm}$ & $\mathrm{R} \$ / \mathrm{cm}^{2}$ & 0.008096 \\
\hline MF-50, thickness $1.25 \mathrm{~mm}$ & $\mathrm{R} \$ / \mathrm{cm}^{2}$ & 0.010454 \\
\hline MF-75, thickness $0.80 \mathrm{~mm}$ & $\mathrm{R} \$ / \mathrm{cm}^{2}$ & 0.008329 \\
\hline MF-75, thickness $0.95 \mathrm{~mm}$ & $\mathrm{R} \$ / \mathrm{cm}^{2}$ & 0.009318 \\
\hline MF-75, thickness $1.25 \mathrm{~mm}$ & $\mathrm{R} \$ / \mathrm{cm}^{2}$ & 0.012031 \\
\hline
\end{tabular}




\section{RESULTS AND DISCUSSIONS}

\subsection{Proposed problem 1: simplified optimized design}

In item 12.7.3, Fakury, Silva and Caldas [24] present a simulation of the most cost-efficient beam distribution for a given slab. Input data for the problem is given below and the answer suggested by the authors are shown in Figure 2.

- Slab dimensions (rectangular): 15 by 6 meters;

- Loading: $0.95 \mathrm{kN} / \mathrm{m}^{2}$ from floor tiling, $0.65 \mathrm{kN} / \mathrm{m}^{2}$ from underdeck ceiling and $6 \mathrm{kN} / \mathrm{m}^{2}$ live load.

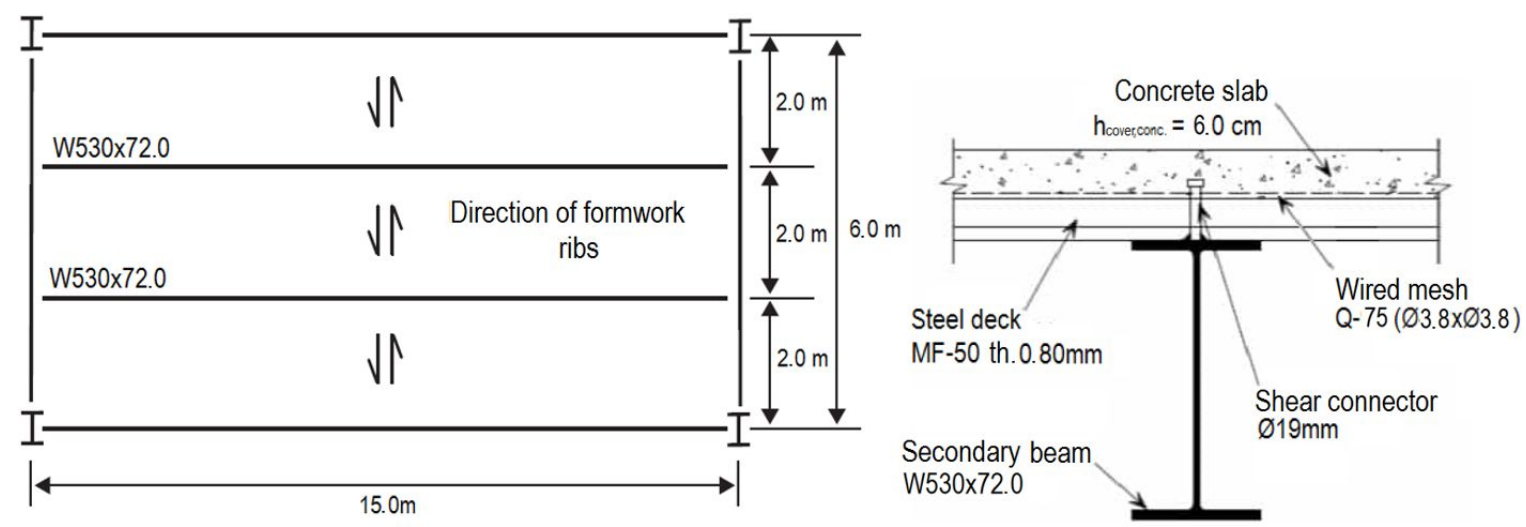

Figure 2 - Proposed problem 1 (Source: Fakury, Silva e Caldas [24], adapted).

To simplify the design optimization, Fakury, Silva and Caldas [24] adopt the lowest possible thickness of steel sheeting, that is, $0.8 \mathrm{~mm}$ and subsequently the following criteria:

1) use the shortest total beam length, regardless of the profiles to be adopted;

2) seek the lowest weight of the slab, which generally corresponds to the slab with the lowest concrete weight.

Table 2 shows the for combinations pertinent to ULS design used.

Table 2 - Loads for the proposed problem 1.

\begin{tabular}{ccccc}
\hline \multirow{2}{*}{ Load } & Characteristic value $\left[\mathbf{k N} / \mathbf{m}^{2}\right]$ & \multirow{2}{*}{ Resistance factor } & \multicolumn{3}{c}{ Design load } \\
\cline { 3 - 5 } & & & Slab $\left[\mathbf{k N} / \mathbf{m}^{\mathbf{2}}\right]$ & Beam $\left._{\mathbf{k} N} / \mathbf{m}^{\mathbf{2}}\right]$ \\
\hline Surfacing weight & 0.95 & $\gamma_{\mathrm{g}}=1.4$ & 0.95 & 1.33 \\
\hline Liner weight & 0.65 & $\gamma_{\mathrm{g}}=1.4$ & 0.65 & 0.91 \\
\hline Live load & 6.00 & $\gamma_{\mathrm{q}}=1.5$ & 6.00 & 9.00 \\
\hline Total & & & 7.60 & 11.24 \\
\hline
\end{tabular}

The answers proposed by Fakury, Silva and Caldas [24] and by the developed software are presented in Table 3, while beam disposition and cross section of the optimized answer found by the software are shown in Figure 3 . Since the former does not present the optimal design of the secondary beams, their geometry was determined with the software, using the data of the slab analyzed in this problem.

Table 3 - Results for the proposed problem 1.

\begin{tabular}{ccc}
\hline & Fakury, Silva e Caldas [24] & Developed software \\
\hline Beam profile & W530x72.0* & W200x15.0 \\
\hline Number of secondary beams & 2 & 6 \\
\hline Interaction Ratio & $0.81^{*}$ & 0.84 \\
\hline Total number of connectors & $76^{*}$ & 72 \\
\hline Length of each beam $[\mathrm{cm}]$ & 1500 & 600 \\
\hline Total length of beams $[\mathrm{cm}]$ & 3000 & 3600 \\
\hline Connector cost $[\mathrm{R} \$]$ & $866.40^{*}$ & 820.8 \\
\hline
\end{tabular}


Table 3 - Continued...

\begin{tabular}{ccc}
\hline & Fakury, Silva e Caldas [24] & Developed software \\
\hline Beams cost $[\mathrm{R} \$]$ & $16931.96^{*}$ & 4173.44 \\
\hline Total cost of beams [R\$] & $17801.36^{*}$ & 4994.24 \\
\hline Sheeting type & MF-50 (th. $0.8 \mathrm{~mm})$ & MF-50 (th. $0.80 \mathrm{~mm})$ \\
\hline Maximum slab span [cm] & 200 & 220 \\
\hline Total slab height [cm] & 11.0 & 13.0 \\
\hline Concrete slab cover height [cm] & 6.0 & 8.0 \\
\hline Slab welded wired mesh & Q-75 $(\Phi 3.8 \times \Phi 3.8-150 \times 150)$ & Q-92 $(\Phi 4.2 \times \Phi 4.2-150 \times 150)$ \\
\hline Sheeting cost [R\$] & $6512.40^{*}$ & 6512.40 \\
\hline Concrete cost [R\$] & $2650.19^{*}$ & 3273.76 \\
\hline Welded wired mesh cost [R\$] & $763.39^{*}$ & 933.73 \\
\hline Total slab cost [R\$] & $9925.98^{*}$ & 10719.9 \\
\hline Total cost of slab and beam [R\$] & $27724.33^{*}$ & 15714.14 \\
\hline
\end{tabular}

* values obtained by the developed software.

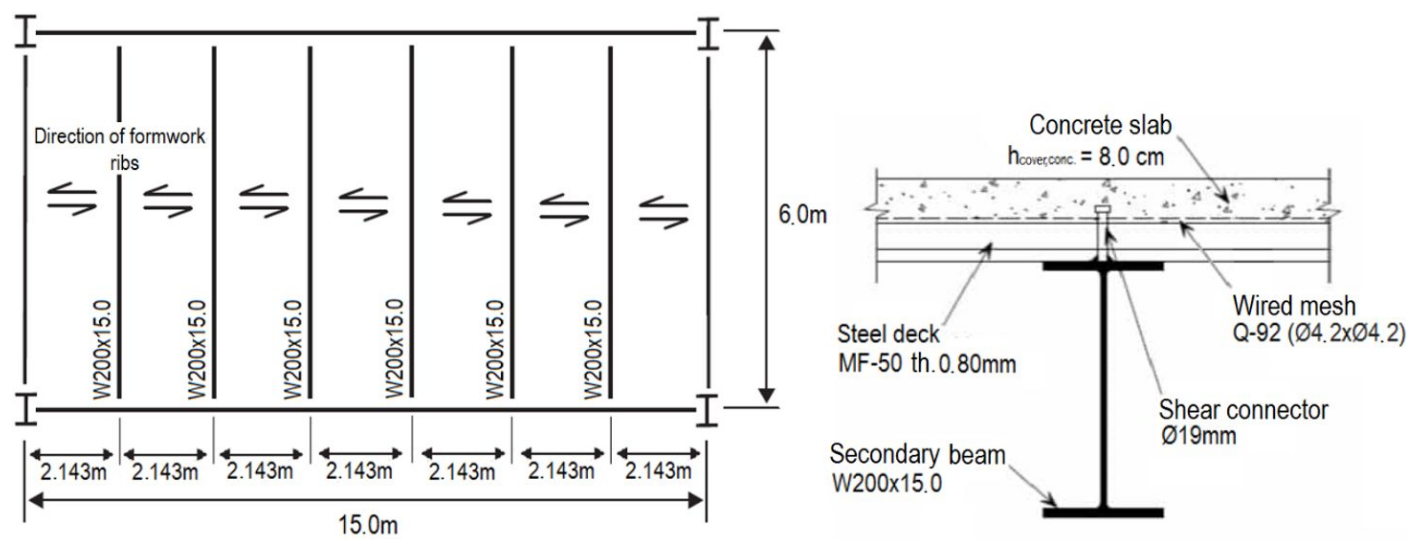

Figure 3 - Solution to the proposed problem 1.

In Figure 4, all the alternatives considered by the software are presented as a function of the total length of the beams and the weight of concrete, to analyze the aforementioned criteria. The pink dots represent the solutions for MF-50, while blue dots are associated with MF-75. The optimal solution is represented by the black crosses.
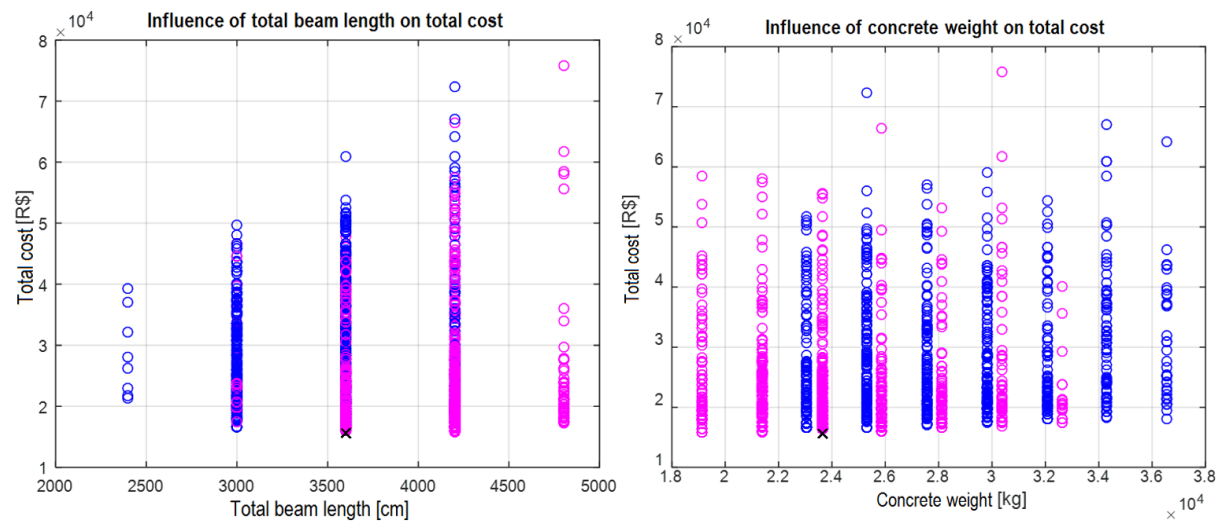

Figure 4 - Influence of beam length and weight of concrete on total cost.

It is noted that non-optimal answers for total length of the beams and concrete weight present solutions close to the optimal design. Figure 5 shows the influence of beam weight and sheeting thickness on total cost. 

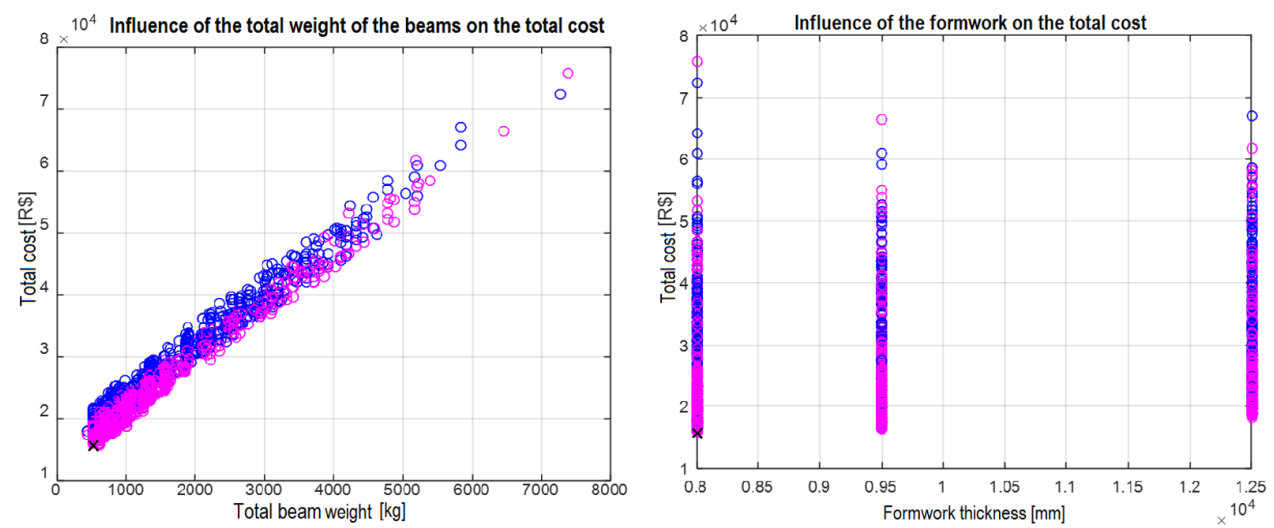

Figure 5 - Influence of the total weight of the beams and the thickness of the formwork on the total cost.

Analyzing the answers obtained as a function of the total weight of the beams (Figure 5) it is noted that the solutions with the lowest beam weight are close to the optimal solution. This would be a good criterion to be adopted in a simplified optimization. However, this information is only obtained after the design procedure.

Figure 4 and Figure 5 also show that, despite the use of MF-50 sheeting resulting in solutions with longer beam lengths, they also indicate lower concrete weights. The use of steel sheeting with thicknesses larger than $0.80 \mathrm{~mm}$ may also lead to answers that are not far from the optimal case.

The answer presented by the software leads to higher costs with concrete and welded wire reinforcement, but results in a set of beams 3.5 times lighter and, consequently, cheaper, making the software a more advantageous option in this case.

The difference observed is justified by the fact that Fakury, Silva and Caldas [24] place the secondary beams parallel to the largest dimension of the slab, thus increasing internal forces, as opposed to the optimal response presented by the software. It is worth mentioning that the differences between these two options can affect the design of the main beams, either decreasing or increasing their cost.

\subsection{Proposed problem 2: Practical example}

To assess the efficiency of the software, an existing building was chosen that uses the composite slab system supported by composite beams. The chosen structure was the headquarters of NEXEM - Nucleus of Excellence in Metallic Structures of UFES (Figure 6) - located in Vitória-ES, Brazil, with a constructed area of $264.98 \mathrm{~m}^{2}$ and structural design by Engineer Pedro Sá and JP Engenharia Ltda. The construction was executed by Denenge - Dinelli Engenharia Ltda and the architectural project by the Architects Augusto Alvarenga, Adriane Alvarenga and Érica Márcia Leite Barros, according to Banco de Obras [30].

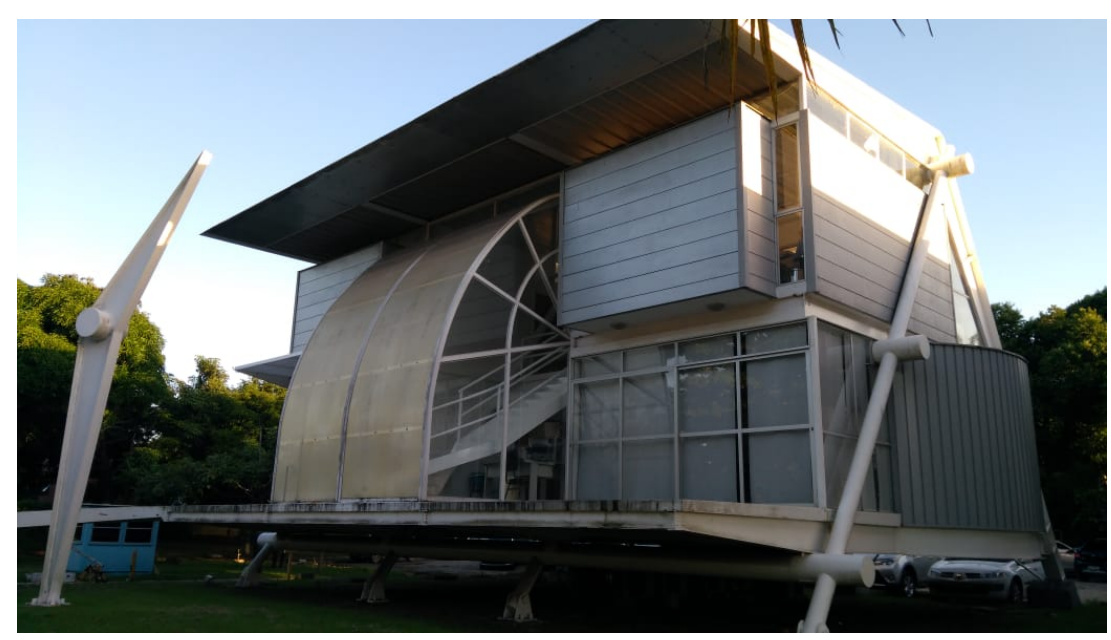

Figure 6 - View of NEXEM. 
Structural parameters used to solve the problem were collected with field measurements. The analyzed slab is shown in its current position in Figure 7 and represented by the scheme of Figure 8. The slab is located on the first floor, used as a classroom, with plane dimensions of $10.5 \mathrm{~m}$ by $4.3 \mathrm{~m}, 15.0 \mathrm{~cm}$ in total height, MF- 50 sheeting, $0.80 \mathrm{~mm}$ thickness and supported by two W200x31.3 secondary beams. The interaction ratio was taken as the minimum allowed value, which implies in the use of 24 shear connectors distributed along the two secondary beams and 30-MPa concrete.

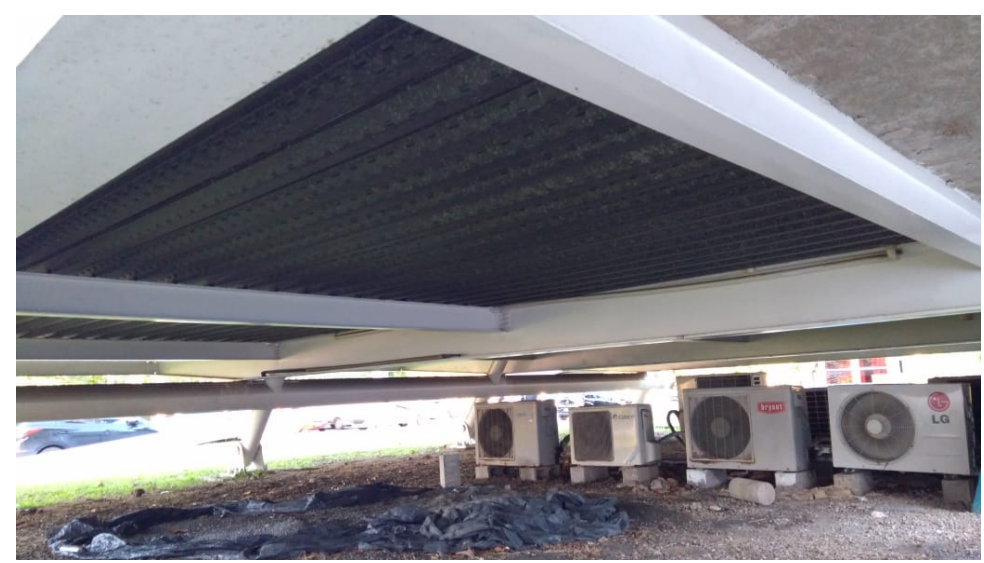

Figure 7 - Detail of the slab analyzed in the proposed problem 2.

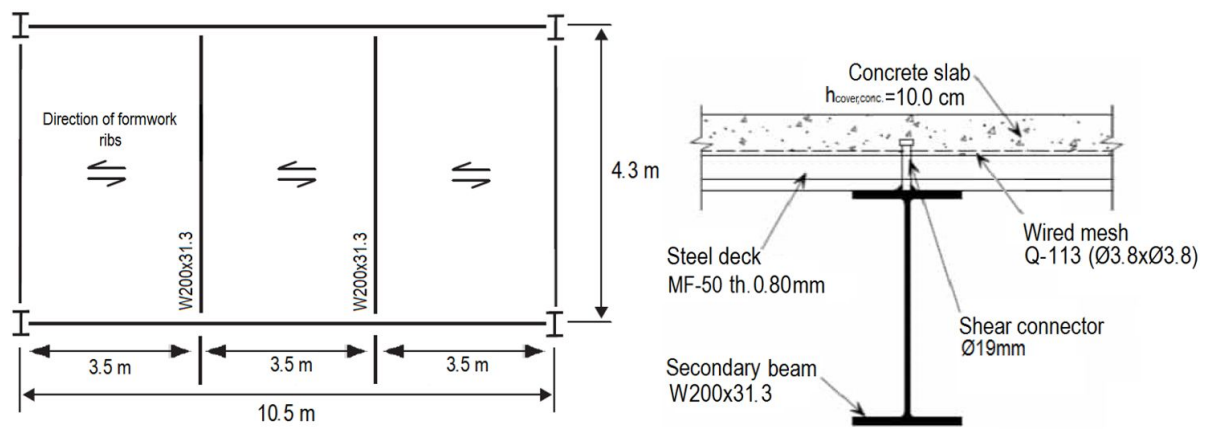

Figure 8 - Proposed problem 2.

Loading was adopted according to ABNT NBR 6120: 1980 [31], which prescribes a live load of $3.0 \mathrm{kN} / \mathrm{m}^{2}$ for classrooms. A $0.4 \mathrm{kN} / \mathrm{m}^{2}$ load is added to account for structural weight, which corresponds to a concrete slab with a thickness of $15 \mathrm{~cm}$. Furthermore, a load of $1.35 \mathrm{kN} / \mathrm{m}^{2}$ is added to account for the weight of surfacing and tiling.

Table 4 shows the combinations of forces used for ULS design.

Table 4 - Loads for the proposed problem 2.

\begin{tabular}{|c|c|c|c|c|}
\hline \multirow{2}{*}{ Load } & \multirow{2}{*}{ Characteristic value $\left[\mathrm{kN} / \mathrm{m}^{2}\right]$} & \multirow{2}{*}{ Resistance factor } & \multicolumn{2}{|c|}{ Design load } \\
\hline & & & Slab $\left[k \mathbf{N} / \mathbf{m}^{2}\right]$ & Beam $\left[\mathrm{kN} / \mathbf{m}^{2}\right]$ \\
\hline Surfacing weight & 1.35 & $\gamma_{\mathrm{g}}=1.4$ & 1.35 & 1.89 \\
\hline Liner weight & 0.40 & $\gamma_{\mathrm{g}}=1.4$ & -- & 0.56 \\
\hline Live load & 3.00 & $\gamma_{q}=1.5$ & 3.00 & 4.50 \\
\hline Total & & & 4.35 & 6.95 \\
\hline
\end{tabular}

Results obtained with the software are shown in Table 5 and illustrated in Figure 9, and indicate a cost reduction of $16 \%$ if compared with the actual structure. Once more, the optimal response does not correspond to the alternative with the shortest beam lengths. However, the software solution yielded the lowest possible concrete weight. 
Table 5 - Results for the proposed problem 2.

\begin{tabular}{|c|c|c|}
\hline & NEXEM & Developed software \\
\hline Beam profile & W200x31.3 & $\mathrm{W} 150 \times 13.0$ \\
\hline Number of secondary beams & 2 & 3 \\
\hline Interaction Ratio & $0.40^{*}$ & 0.52 \\
\hline Total number of connectors & $24 *$ & 18 \\
\hline Length of each beam [cm] & 430 & 430 \\
\hline Total length of beams $[\mathrm{cm}]$ & 860 & 1290 \\
\hline Connector cost $[\mathrm{R} \$]$ & $273.60 * *$ & 205.20 \\
\hline Beams cost $[\mathrm{R} \$]$ & $2121.06^{* *}$ & 1268.96 \\
\hline Total cost of beams [R\$] & $2394.66^{* *}$ & 1474.16 \\
\hline Sheeting type & MF-50 (th. $0.8 \mathrm{~mm}$ ) & MF-50 (th. $0.95 \mathrm{~mm}$ ) \\
\hline Maximum slab span $[\mathrm{cm}]$ & 350 & 270 \\
\hline Total slab height $[\mathrm{cm}]$ & 15 & 11 \\
\hline Concrete slab cover height $[\mathrm{cm}]$ & 10 & 6 \\
\hline Slab welded wired mesh & Q-113 (Ф3.8xФ3.8 - 100x100)* & Q-75 (Ф3.8xФ3.8 - 150x150) \\
\hline Sheeting cost $[\mathrm{R} \$]$ & $3267.05^{* *}$ & 3655.34 \\
\hline Concrete cost $[\mathrm{R} \$]$ & $1955.16^{* *}$ & 1329.51 \\
\hline Welded wired mesh cost [R\$] & $569.70 * *$ & 382.97 \\
\hline Total slab cost $[\mathrm{R} \$]$ & $5791.92 * *$ & 5367.82 \\
\hline Total cost of slab and beam [R\$] & $8168.58 * *$ & 6841.99 \\
\hline
\end{tabular}

* values adopted. ** values obtained by the developed software.

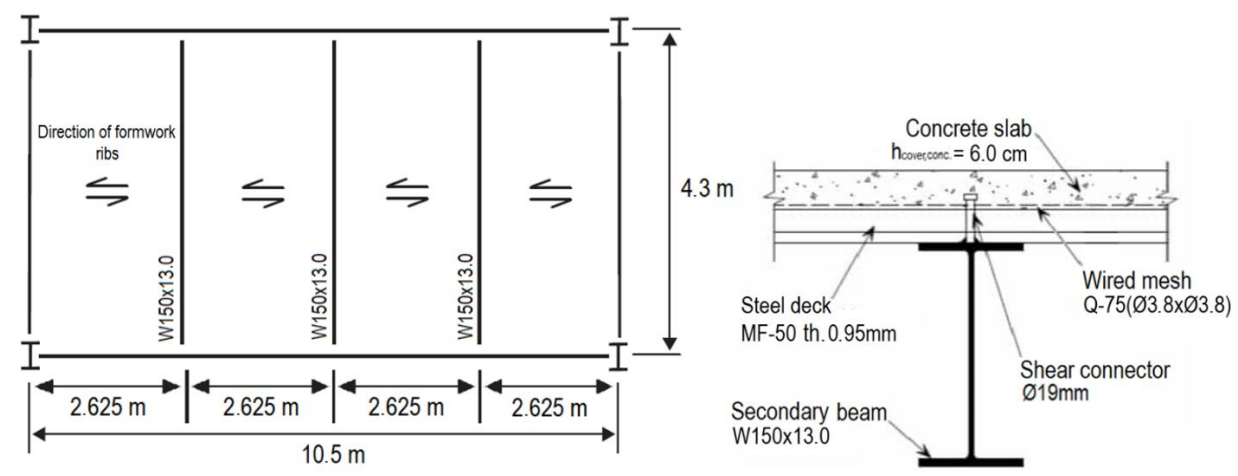

Figure 9 - Solution to the proposed problem 2.

Figure 10 shows a graph comparing the costs of each element of the optimized structural system.

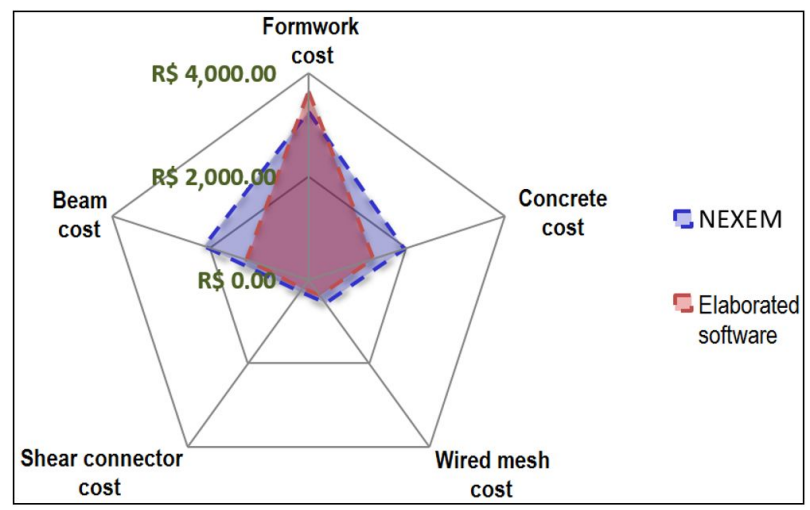

Figure 10 - Comparison of costs per item. 
The graph shows that, even though the software presents a solution with the highest cost of steel sheeting, which is the most expensive item, lower expenses with remaining resources are observed. As such, even with the increased value to obtain the most expensive item in the system, overall cost is still reduced.

Geometric properties of the steel profiles were obtained disregarding the additional cross-sectional area associated with the radius of curvature between the web and the laminated profile flanges. This assumption aims to simplify calculations and it is a conservative determination. The properties of the steel profiles shown in this research are shown in Table 6.

Table 6 - Geometric properties of the beam profiles used.

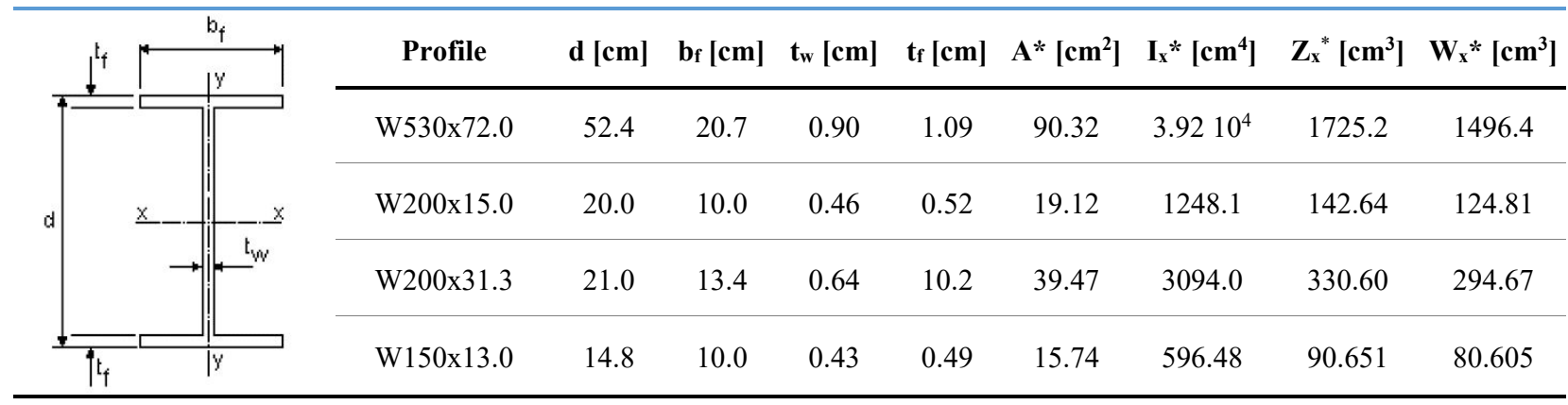

* Calculated without considering the forming radius between flanges and web of the laminated profiles.

\subsection{Time analysis}

During the solution of the first problem proposed, the software spent an average of 0.627 seconds to analyze a generation with 60 individuals. Considering the universe of 13,516,800 individuals, the program would need 39.2 hours to analyze all possible alternatives and return the optimal answer. Using the GA, the developed software analyzed only 3120 individuals and found the optimal response in 32 seconds.

\section{CONCLUSION}

Results obtained from the application of the developed software to proposed problems indicate that the program is an efficient tool for optimization of structural systems composed of steel-concrete composite beams and slabs.

In Proposed Problem 1, although the criteria suggested by Fakury, Silva and Caldas [24] lead to a low-cost slab, the use of GA allowed for a more comprehensive optimization, and consequently, a better result.

In Proposed Problem 2, part of the difference observed may be a result of design considerations such as: additional loads, suitability for SLS, among others. Even so, the use of GA can lead to significant improvements, since the software solution indicated the possibility of using a lighter set of beams, in greater number, resulting in a smaller slab span and, consequently, reductions in cost and weight of concrete.

Results also show that the use of discrete variables obtained from commercial tables provided by the manufacturers, combined with knowledge of the actual market prices of each structural element and the use of GA as a method of optimization, lead to structural systems that are well optimized and close to practical scenarios.

Finally, the use of GA allows an alternative approach to structural design, perhaps even replacing the pre-design phase, since the algorithm itself can simulate an initial solution and, by an iterative process, converge to the optimal design.

\section{REFERENCES}

[1] J. A. Lazzari, E. C. Alves, and A. F. G. Calenzani “'Optimum design of spatial steel frames according to ABNT NBR 8800:2008,” in XIII SIMMEC, Vitória, ES, Brasil, 2018.

[2] G. P. Lubke, E. C. Alves, and M. S. Azevedo “Optimum design and failure modes analysis of steel alveolar beams,” REA - CBCA, vol. 6, p. 1-20, 2017.

[3] B. D. Breda, N. G. P. Salgado, W. L. Siqueira, E. C. Alves, and A. F. G. Calenzani “Utilização de Algoritmo Genético na Otimização de Vigas Mistas Biapoiadas de Aço e Concreto," in XIII SIMMEC, Vitória, ES, Brasil, 2018.

[4] METFORM. "Steel Deck: a solução definitiva em lajes." http://www.metform.com.br/wordpress/wpcontent/uploads/2015/05/steel_deck_metform.pdf(accessed May 13, 2019).

[5] C. Liu, A. Hammad, and Y. Itoh, "Multiobjective Optimization of Bridge Deck Rehabilitation Using a Genetic Algorithm," Microcomputers Civ. Eng., vol. 12, pp. 431-443, 1997. 
[6] H. Cho, D. Min, and K. Lee “Optimum Life-Cycle Design of Orthotropic Steel Deck Bridges,” Steel Struct., vol. 1, pp. 141-152, 2001.

[7] C. K. Fu, Y. Zhai, and S. Zhou “Optimum Design of Welded Steel Plate Girder Bridges Using a Genetic Algorithm with Elitism,” J. Bridge Eng., vol. 10, pp. 291-301, 2005.

[8] D. A. Souza Jr., "Otimização pelo método dos algoritmos genéticos e dimensionamento de estruturas tubulares metálicas espaciais com barras cruzadas para cobertura,” Ph.D. thesis, DEC, UFU, Uberlândia, MG, 2005.

[9] J. Câmara Neto, A. Landesmann, and E. M. Batista “Aplicação de Algoritmos Genéticos para Dimensionamento de Vigas-Mistas Aço-Concreto," in CONSTRUMETAL 2008 - Latin-American Congress on Steel Construction, São Paulo, SP, 2008.

[10] T. L. D. Forti, M. G. Q. Souza, and J. A. V. Requena "Desenvolvimento de um Algoritmo Genético para Otimização de Grandes Estruturas de Aço para Coberturas," in XXX Ibero-Latin-American Congress on Computational methods in Engineering, Armação de Búzios, Rio de Janeiro, 2009, pp. 1-18.

[11] M. L. R. Lima, “Otimização topológica e paramétrica de vigas de concreto armado utilizando algoritmos genéticos,” M.S. thesis, DEC, USP, São Paulo, SP, 2011.

[12] P. Kripakaran, B. Hall, and A. Gupta, "A genetic algorithm for design of moment-resisting steel frames," Struct. Multidiscipl. Optim., vol. 44, no. 4, pp. 559-574, 2011.

[13] M. Kociecki and H. Adeli, "Shape optimization of free-form steel space-frame roof structures with complex geometries using evolutionary computing," Eng. Appl. Artif. Intell. Elsevier, vol. 38, pp. 168-182, 2015.

[14] M. B. Prendes-Gero, A. Bello-García, J. J. Coz-Díaz, F. J. Suárez Domínguez and P. J. G. Nieto, "Optimization of steel structures with one genetic algorithm according to three international building codes," Rev. Constr., vol. 17, no. 1, pp. 47-59, 2018.

[15] H. F. X. A. Bilbao, "Dimensionamento de absorvedores de massa sintonizada para lajes duplo T pré-fabricadas em concreto por meio de algoritmo genético,” Undergraduate thesis, UTFPR, Curitiba, PR, Brasil, 2016.

[16] L. A. Bezerra, "Emprego de algoritmos genéticos para otimização de vigas de concreto armado,” Master’s thesis, UFPE, Recife, PE, 2017.

[17] J. Malveiro, D. Ribeiro, C. Souza, and R. Calçada, "Model updating of a dynamic model of a composite steel-concrete railway viaduct based on experimental tests," Eng. Struct., vol. 164, p. 40-52, 2018.

[18] N. L. A. Lima, J. G. S. Silva, F. J. C. P. Soeiro, L. Biondi No, and L. R. O. Lima, "Avaliação do conforto humano de passarelas mistas com o uso de algoritmos genéticos," Engevista, vol. 10, no. 1, pp. 59-70, 2008.

[19] R. P. B. C. Pereira, “Otimização de um projeto estrutural de ponte em viga mista,” Undergraduate thesis, UniCEUB, Brasília, DF,Brasil, 2016.

[20] G. S. Papavasileiou and D. C. Charmpis "Seismic design optimization of multi-storey steel-concrete composite buildings," Comput. Struct., vol. 170, p. 49-61, 2016.

[21] A. R. Silva, and T. A. Rodrigues, “Optimized dimensioning of steel-concrete composite beams,” Rev. IBRACON Estrut. Mater., vol. 12, no. 6, p. 1428-1453, Dec. 2019.

[22] A. F. Tormen, Z. M. C. Pravia, F. B. Ramires, and M. Kripka, "Optimization of steel concrete composite beams considering cost and environmental impact," Steel Compos. Struct., vol. 34, no. 3, pp. 409-421, Feb 2020., http://dx.doi.org/10.12989/scs.2020.34.3.409.

[23] Associação Brasileira de Norma Técnicas, Projeto de Estruturas de Aço e de Estruturas Mistas de Aço e Concreto de Edificios - Procedimento, ABNT NBR 8800:2008, Rio de Janeiro, 2008.

[24] R. H. Fakury, A. L. R. Silva, and R. B. Caldas, "Dimensionamento de elementos estruturais de aço e mistos de aço e concreto," 1. ed. São Paulo, Brasil: Pearson Education do Brasil, 2016.

[25] MATLAB. “Userguide R2015a.” São Paulo, SP, Brasil: The Math Works Inc, 2015.

[26] GERDAU. “Perfil Estrutural.” https://www2.gerdau.com.br/produtos/perfil-estrutural (accessed May 13, 2019).

[27] Sistema Nacional de Pesquisa de Custos e Índices da Construção Civil. http://www.caixa.gov.br/poder-publico/apoio-poderpublico/sinapi/Paginas/default.aspx (accessed Mar. 19, 2019).

[28] F. C. R. Cordeiro, “Análise de produtividade da mão-de-obra e composição de custos do serviço de execução da laje steel deck,” Undergraduate thesis, UFSC, Florianópolis, SC, 2016.

[29] MS Estruturas Metálicas. "Painel Steel Deck." https://rms-estruturas-metalicas.webnode.com.pt/products/painel-steel-deck-apartir-de-r\%2446\%2C35-m\%C2\%B2/. (accessed Mar. 15, 2019).

[30] CBCA. "Banco de Obras.” http://www.cbca-acobrasil.org.br/banco-de-obras/obra/edificio-sede-do-nexem---vitoria/es. (accessed Mar. 18, 2019).

[31] Associação Brasileira de Norma Técnicas, Associação Brasileira de Norma Técnicas. Cargas para o cálculo de estruturas de edificações Procedimento, ABNT NBR 6120:1980, Rio de Janeiro, 1980.

Author contributions: BDB: conceptualization, data curation, formal analysis, methodology, writing; TCP: conceptualization, writing; ECA: conceptualization, supervision, writing.

Editors: Bernardo Horowitz, José Luiz Antunes de Oliveira e Sousa, Guilherme Aris Parsekian. 